\title{
EFFECT OF HEAT INPUT ON THE MICROSTRUCTURE AND MECHANICAL PROPERTIES OF AN ELECTRON-BEAM-WELDED AZ31 MAGNESIUM ALLOY
}

\author{
VPLIV VNOSA TOPLOTE NA MIKROSTRUKTURO IN \\ MEHANSKE LASTNOSTI Z ELEKTRONSKIM SNOPOM VARJENE \\ MAGNEZIJEVE ZLITINE AZ31
}

\author{
Chen Jinqiu ${ }^{1}$, Li Fei ${ }^{1}$, Wu Zhisheng ${ }^{1 *}$, Lyu Weigang ${ }^{2}$ \\ ${ }^{1}$ School of Materials Science and Engineering, Taiyuan University of Science and Technology, Taiyuan 030024, No.66, Waliu Road, \\ Wanbailin District, Shanxi, PR China \\ ${ }^{2}$ Shanxi Fenxi Heavy Industry Co., Ltd, Taiyuan 030027, PR China
}

Prejem rokopisa - received: 2020-05-07; sprejem za objavo - accepted for publication: 2020-07-24

\author{
doi: $10.17222 /$ mit. 2020.073
}

\begin{abstract}
The effect of heat input on the microstructure and mechanical properties of an electron-beam-welded AZ31 magnesium alloy were investigated. Using tensile tests, it was found that the strength of the welded joints was better than that of the base metal. However, the ductility became much worse after the electron-beam welding. The heat input plays a key role in electron-beam welding for the AZ31 magnesium alloy. The results showed that both the strength and the ductility exhibited the trend of increasing first and then decreasing with increasing heat inputs, and reached their maximum values at $180 \mathrm{~J} \cdot \mathrm{mm}^{-1} \mathrm{and} 216 \mathrm{~J} \cdot \mathrm{mm}^{-1}$, respectively. It is closely related to the macro morphologies and microstructures of the welds under different heat inputs. With increasing heat inputs, the appearances of the welds changed from nail-shape to straight-shape, which is more conducive to reducing the stress concentration during tensile deformation, the grains in the fusion zone became coarser. $\mathrm{Many}_{\mathrm{Mg}} \mathrm{Mg}_{17} \mathrm{Al}_{12}$ precipitates were observed in the grains of the weld. A large heat input led to an increase in the quantity and size of the precipitates in the weld. These precipitates effectively restricted the dislocation movement and improve the strength. Significantly, the fracture morphological difference between the fusion zone and base metal can be found. The fracture morphology in the base metal side was polyhedral, which was generally intergranular fracture. However, the brittle fracture was not obvious in the fusion region of the weld. Instead, a large number of fine dimples were observed at high magnification.
\end{abstract}

Keywords: AZ31 magnesium alloy, heat input, microstructure, mechanical properties

Avtorji v pričujočem članku opisujejo raziskavo vpliva vnosa toplote med varjenjem magnezijeve zlitine AZ31 na mikrostrukturo in mehanske lastnosti zvarov. Z nateznimi preizkusi so ugotovili, da so natezne trdnosti varjenih spojev boljše kot trdnost osnovne zlitine. Vendar pa se je duktilnost zvarov močno poslabšala. Vnos toplote, med varjenjem Mg zlitine AZ31 z elektronskim snopom, igra pri tem ključno vlogo. Rezultati raziskave kažejo, da tako trdnost kot tudi duktilnost zvarov z naraščanjem vnosa toplote, najprej naraščata nato pa začneta padati in dosežeta maksimalne vrednosti pri vnosu toplote 180 $\mathrm{J} \cdot \mathrm{mm}^{-1} \mathrm{oz} .216 \mathrm{~J} \cdot \mathrm{mm}^{-1}$. To je tesno povezano s spremembo makro-morfologije prelomov zvarov in njihove mikrostrukture glede na spremembo vnosa toplote. Z naraščanjem vnosa toplote se metalografski izgled zvarov spreminja od koničaste oblike nohtov do ravnih, ki bolj blažijo oz. zmanjšajo koncentracijo napetosti med natezno deformacijo in kristalna zrna v coni taljenja postanejo bolj groba. V kristalnih zrnih zvarov se nahaja mnogo izločkov $\mathrm{Mg}_{17} \mathrm{Al}_{12}$. Večji vnos toplote vodi do povečanja količine in velikosti teh izločkov. Ti izločki učinkovito omejujejo gibanje dislokacij, kar povečuje mehansko trdnost zvarov. Morfologije prelomov v kovinski osnovi in coni taljenja zvarov se močno razlikujejo med seboj. Morfologija prelomov v osnovni kovini ima poliedrična kristalna zrna $\mathrm{z}$ intergranularnim prelomom. Vendar pa v nasprotju s pričakovanjem, prelomi zvarov v področju taljenja niso imeli značilne krhke morfologije. Namesto tega so opazili prisotnost velikega števila finih duktilnih jamic pri velikih povečavah.

Ključne besede: magnezijeva zlitina AZ31, vnos toplote, mikrostruktura, mehanske lastnosti

\section{INTRODUCTION}

Magnesium alloys have become some of the most important lightweight metal materials due to their excellent performance such as high specific strength, high specific stiffness, vibration absorption and noise reduction, strong electromagnetic shielding ability, energy saving and environmental protection. ${ }^{1-3}$ They are widely used in the aerospace industry, automobile manufacturing industry, $3 \mathrm{C}$ industry and other fields. ${ }^{4,5}$ However, due to their

*Corresponding author's e-mail:

Wuzhisheng_tyust@126.com (Wu Zhisheng) active chemical property and high heat conductivity, magnesium alloys must be welded at high power under a flux or vacuum environment. They are prone to welding defects, such as inclusions, coarse grains, wide heat-affected zone, cracks and pores in the magnesium alloy joint by using traditional welding methods. ${ }^{6,7}$ These defects can cause large mechanical properties differences between the joint and the base metal (BM).

Electron-beam welding (EBW) can effectively avoid the aforementioned defects. ${ }^{8}$ The energy density of EBW can reach $10^{6} \approx 10^{9} \mathrm{~W} / \mathrm{cm}^{2} .{ }^{9}$ The joints with a large depth-to-width ratio and narrow heat-affected zone can be achieved..$^{10}$ And because of its vacuum environment, it 
can effectively prevent the nitrogen and oxygen elements from entering the weld pools and affecting the joints' quality. ${ }^{11} \mathrm{EBW}$ are more suitable for magnesium alloy plates.

The main parameters of EBW include accelerating voltage, electron beam current, focusing current and welding speed. As a comprehensive consideration of these welding parameters, the heat input can be used to evaluate the energy applied to the fusion zone of the joints. Many studies show that the heat input of EBW has a large influence on the microstructure and properties of the joints. ${ }^{12-15}$ In the study of Zhang et al, ${ }^{12}$ the influence of heat input in EBW process on the microstructure, mechanical properties of duplex stainless-steel welded joints was investigated. In their result, it pointed that an increase in heat input promotes the growth of grain boundary austenite and the formation of fine intragranular austenite. The EBW joints had significantly higher microhardness than the BM and the EBW weld had relatively lower toughness than the BM. Gao et al. ${ }^{13}$ investigated the mechanical behaviors and microstructure evolution of titanium alloy EBW joints. The results show that for small heat input (SHI) weld metal, martensite $\alpha$ ' phase was wide and intertwined and the residual $\beta$ was relatively high. For a large heat input (LHI), martensite $\alpha$ ' was relatively small. While hardness of the LHI weld metal is consistent. The fracture locations of LHI EBW joint specimens are in the base metal, and the UTS of the joints reaches $935 \mathrm{MPa}$. The fracture locations of the SHI EBW joint specimens are in weld metal, and the UTS of the joints reach about $905 \mathrm{MPa}$. Feng et al. ${ }^{15}$ studied the microstructure evolution of an electron-beam-welded Ti3Al-Nb joint. As the heat input is decreased, the cellular structure zone is significantly reduced, and then the crystallizing morphology of the fusion zone presented a dendritically columnar structure. There existed grain growth coarsening in the heat-affected zone (HAZ) for insufficient polygonization. Both the fusion zone (FZ) and the HAZ had a higher microhardness than the BM.

However, few studies focus on the effect of heat input on the microstructure and mechanical properties of magnesium alloy welded joints. $\mathrm{Chi}^{16}$ analyzed the relationship between the parameters and defects for the EBW of AZ-series magnesium alloy using the Taguchi method. It reported that the parameters for EBW of AZ-series magnesium alloys may be ranked in order of decreasing influence as follows: beam oscillation, focal position, stress relief, material difference, beam current, welding speed, and accelerating voltage. But, the microstructure evolution with different heat input were rarely discussed.

The main purpose of this study is to investigate the microstructure and mechanical properties of AZ31 magnesium alloy welded joints with a different heat input. The tensile fracture mechanisms were discussed by SEM observation. The relation between the microstructure and

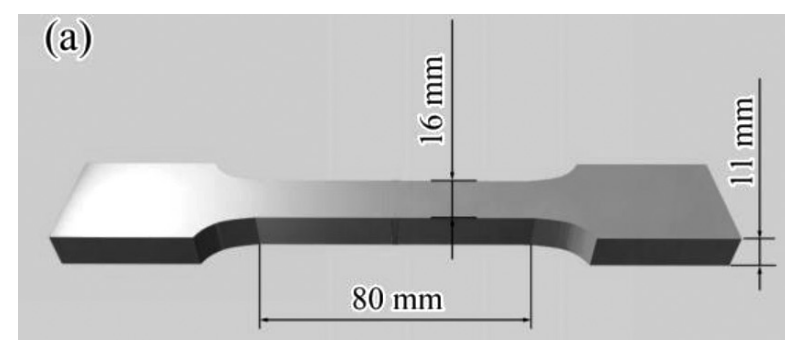

(b)

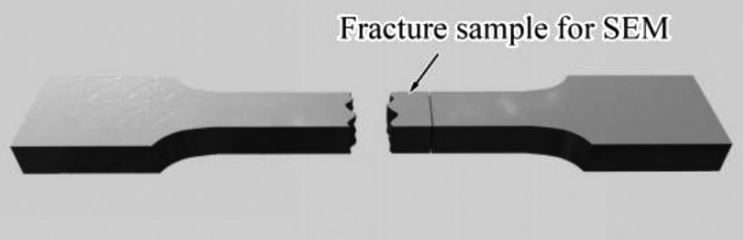

(c)

Metallographic sample

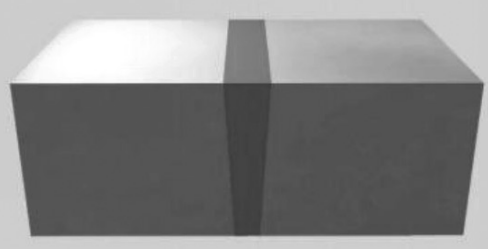

(d)

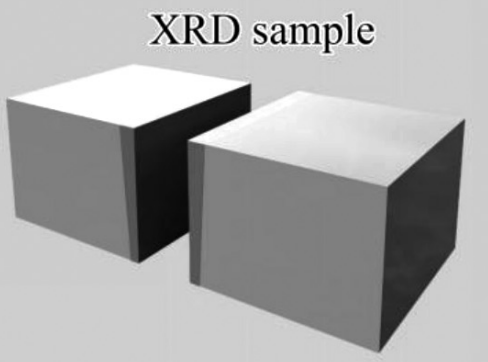

(e) TEM sample

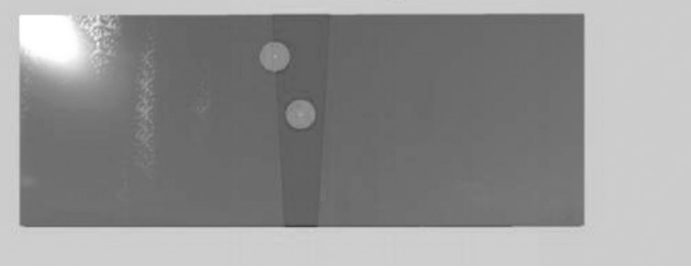

Figure 1: Schematic diagram of sampling method for various inspection purposes: a) tensile specimen, b) fracture sample, c) metallographic sample, d) XRD sample, e) TEM sample 
the mechanical behavior of the AZ31 EBW joints was investigated by $\mathrm{OM}$ and TEM observations.

\section{EXPERIMENTAL PART - MATERIAL AND METHOD}

AZ31 magnesium alloy extrusion plates with thickness of $11 \mathrm{~mm}$ were used in this study. The nominal chemical compositions of the AZ31 plates are listed in Table 1. Before welding, the oxide layer of the plate was machined and any surface was cleaned with acetone. A GENOVA EBW machine was employed in the test. All butt-welding tests were conducted in a vacuum $\left(8 \times 10^{-4}\right.$ mbar) environment without filler metal. Four different sets of welding parameters were carried out, as is shown in Table 2. The heat inputs are in the range 150-252 $\mathrm{J} \cdot \mathrm{mm}^{-1}$.

Table 1: Chemical compositions of AZ31 magnesium alloy

\begin{tabular}{|c|c|c|c|c|c|c|c|}
\hline $\mathrm{Al}$ & $\mathrm{Zn}$ & $\mathrm{Mn}$ & $\mathrm{Fe}$ & $\mathrm{Si}$ & $\mathrm{Cu}$ & $\mathrm{Ni}$ & $\mathrm{Mg}$ \\
\hline 3.16 & 1.04 & 0.30 & 0.0082 & 0.033 & 0.0022 & 0.00043 & Bal. \\
\hline
\end{tabular}

Three tensile specimens for each welding parameter were sectioned from the EBW joints perpendicular to the welding direction. The tensile specimens of the BM were also machined for the purpose of comparison. All the tensile specimens were milled on the surface and bottom in order to prevent the stress-concentration from affecting the results. Tensile tests were performed on a SUNS electronic universal testing machine with a constant strain rate of $0.001 \mathrm{~s}^{-1}$ at room temperature. Metallographic observations of the EBW joint samples were conducted on an Axio Imager A1m optical microscope $(\mathrm{OM})$. Fracture morphologies of the tensile samples were observed on an Hitachi S-4800 scanning electron microscope (SEM). Thin foils for TEM testing were first mechanically polished down to about $50 \mu \mathrm{m}$, then ion milled by Leica EM RES102 ion beam thinner. TEM ob-

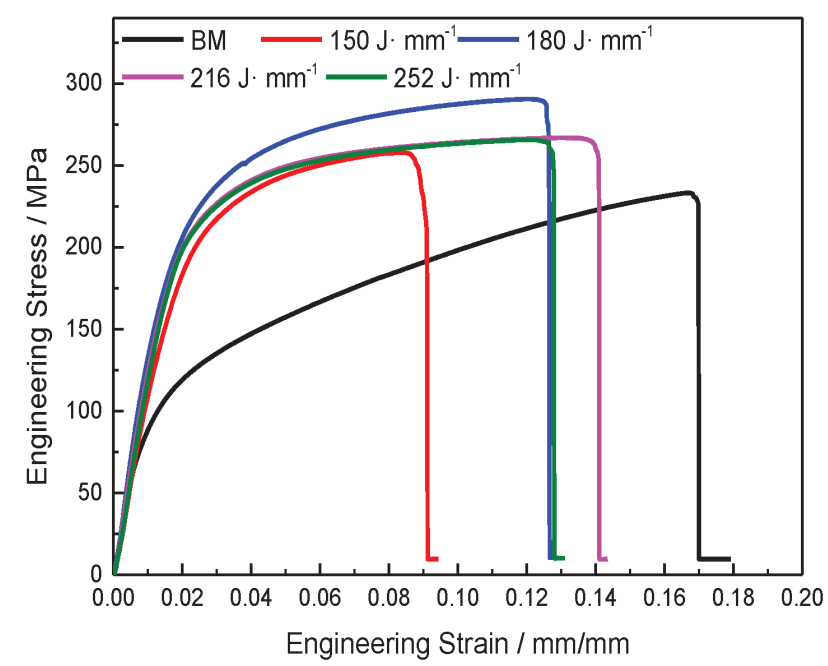

Figure 2: Tensile engineering stress-strain curves of AZ31 magnesium alloy BM and EBW joints servations were conducted on a JEM-F200. The phase constitutes in the specimens were analyzed by X-ray diffraction (XRD). Sampling methods for all inspection purposes are shown in Figure 1.

Table 2: Parameters of electron beam welding of AZ31 magnesium alloy

\begin{tabular}{|c|c|c|c|c|c|}
\hline No. & $\begin{array}{c}\text { Acceler- } \\
\text { ated volt- } \\
\text { age } / \mathrm{kV}\end{array}$ & $\begin{array}{c}\text { Beam } \\
\text { current } \\
/ \mathrm{mA}\end{array}$ & $\begin{array}{c}\text { Focused } \\
\text { current } \\
\text { /A }\end{array}$ & $\begin{array}{c}\text { Welding } \\
\text { speed } \\
/ \mathrm{mm} \cdot \mathrm{min}^{-1}\end{array}$ & $\begin{array}{c}\text { Heat input } \\
/ \mathrm{J} \cdot \mathrm{mm}^{-1}\end{array}$ \\
\hline 1 & 50 & 50 & 2.14 & 1000 & 150 \\
\hline 2 & 60 & 50 & 2.14 & 1000 & 180 \\
\hline 3 & 60 & 60 & 2.14 & 1000 & 216 \\
\hline 4 & 60 & 70 & 2.14 & 1000 & 252 \\
\hline
\end{tabular}

\section{RESULTS}

\subsection{Tensile properties}

The tensile engineering stress-strain curves of the AZ31 magnesium alloy BM and EBW joints are shown in Figure 2. It indicated that the initial $0.2 \%$ yield strength (YS) of the AZ31 magnesium alloy BM is about 95.1 $\mathrm{MPa}$, and the ultimate tensile strength (UTS) is 233.2 MPa. It can be seen that the elongation of the BM specimen is the best compared with EBW joints. But the
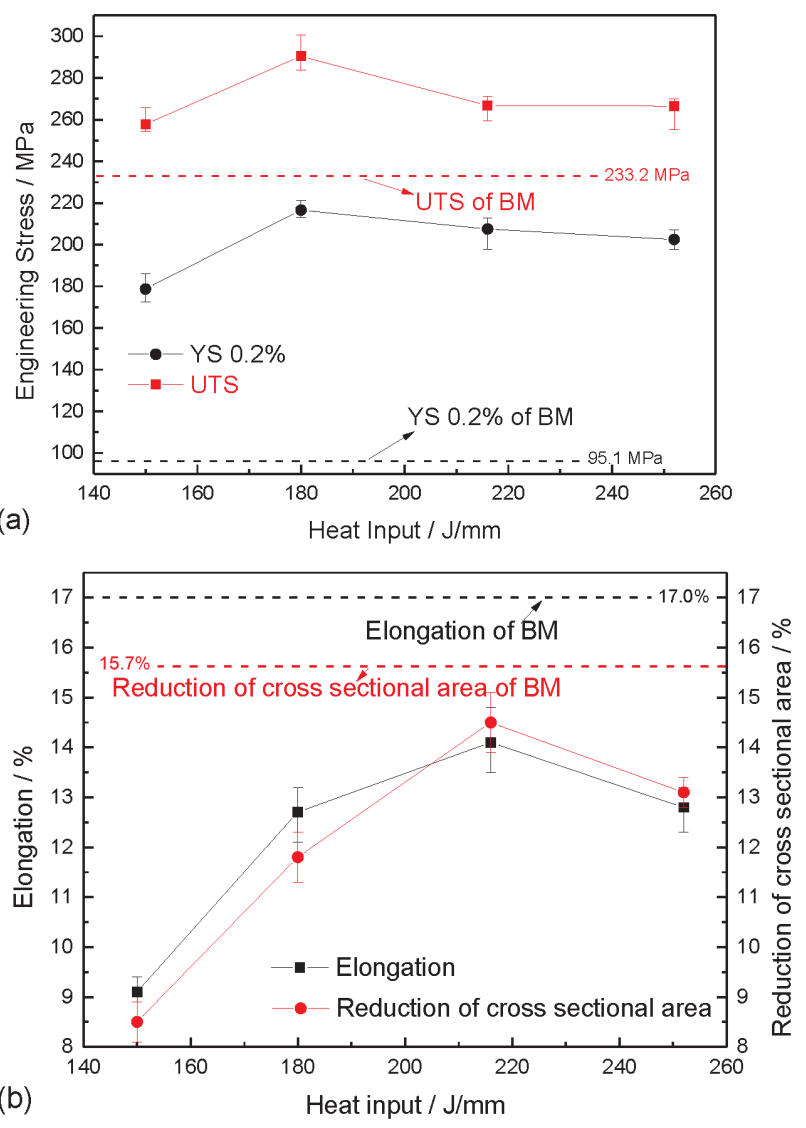

Figure 3: Strength and ductility of AZ31 magnesium alloy joints with different heat inputs: a) the initial $0.2 \%$ yield strength and ultimate tensile strength, b) the elongation and reduction of cross sectional area 
initial $0.2 \%$ yield strength and ultimate tensile strength of the BM are worse than that of the EBW specimens. A similar result was found in the study of $\mathrm{Su}$ et al. ${ }^{17}$ In their study, the EBW behavior in the Mg-Al based alloys was investigated. They attributed the high strength of the joints to the forming of fine grains in the fusion zone. Figure 3 shows the strength and ductility of AZ31 magnesium alloy joints under different heat inputs. In Figure 3a, the YS and UTS first increase and then decrease with the increasing of the heat input. With a heat input of 150 $\mathrm{J} \cdot \mathrm{mm}^{-1}$, the strength of the joint is the worst of all. The YS and UTS are 178.7 $\mathrm{MPa}$ and 257.8 $\mathrm{MPa}$, respectively. The specimen with a heat input of $180 \mathrm{~J} \cdot \mathrm{mm}^{-1}$ has the highest strength. The YS and UTS are 216.6 MPa and 290.4 $\mathrm{MPa}$, which increase by $121.5 \mathrm{MPa}$ and 57.2 MPa compared with the BM. As shown in Figure $3 \mathrm{~b}$, the variations of ductility are similar to that of strength, which are increased first and then decrease. The ductility of the specimen with $150 \mathrm{~J} \cdot \mathrm{mm}^{-1}$ is the worst. The elongation and reduction of cross-sectional area are respectively $9.1 \%$ and $8.5 \%$. With the heat input of 216 $\mathrm{J} \cdot \mathrm{mm}^{-1}$, the value of elongation and reduction of cross sectional area are relatively high, i.e., only $2.9 \%$ and $2.5 \%$ smaller than the BM.

\subsection{Metallographic observations}

Figure 4 shows the weld appearances of the EBW AZ31 joints under different heat inputs in this study. It can be seen that all the welds are full penetration. With the increase of heat input, the top side of the weld is slightly broadened and the bottom of the weld is signifi-

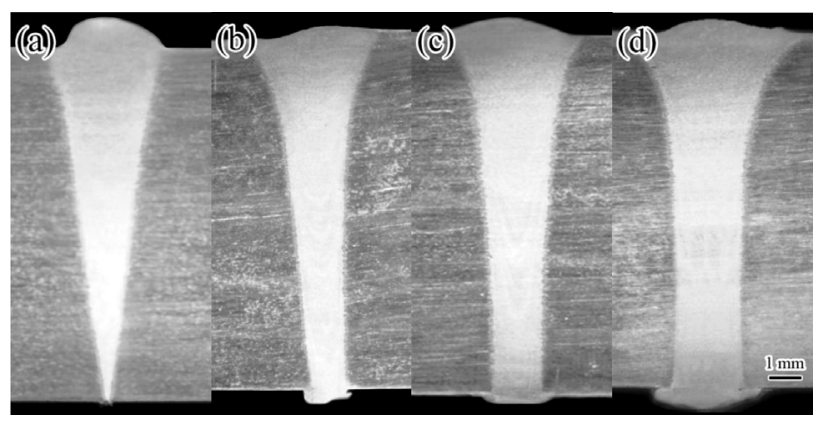

Figure 4: The weld appearances under different heat input: a) $150 \mathrm{~J} \cdot \mathrm{mm}^{-1}$, b) $180 \mathrm{~J} \cdot \mathrm{mm}^{-1}$, c) $216 \mathrm{~J} \cdot \mathrm{mm}^{-1}$, d) $252 \mathrm{~J} \cdot \mathrm{mm}^{-1}$

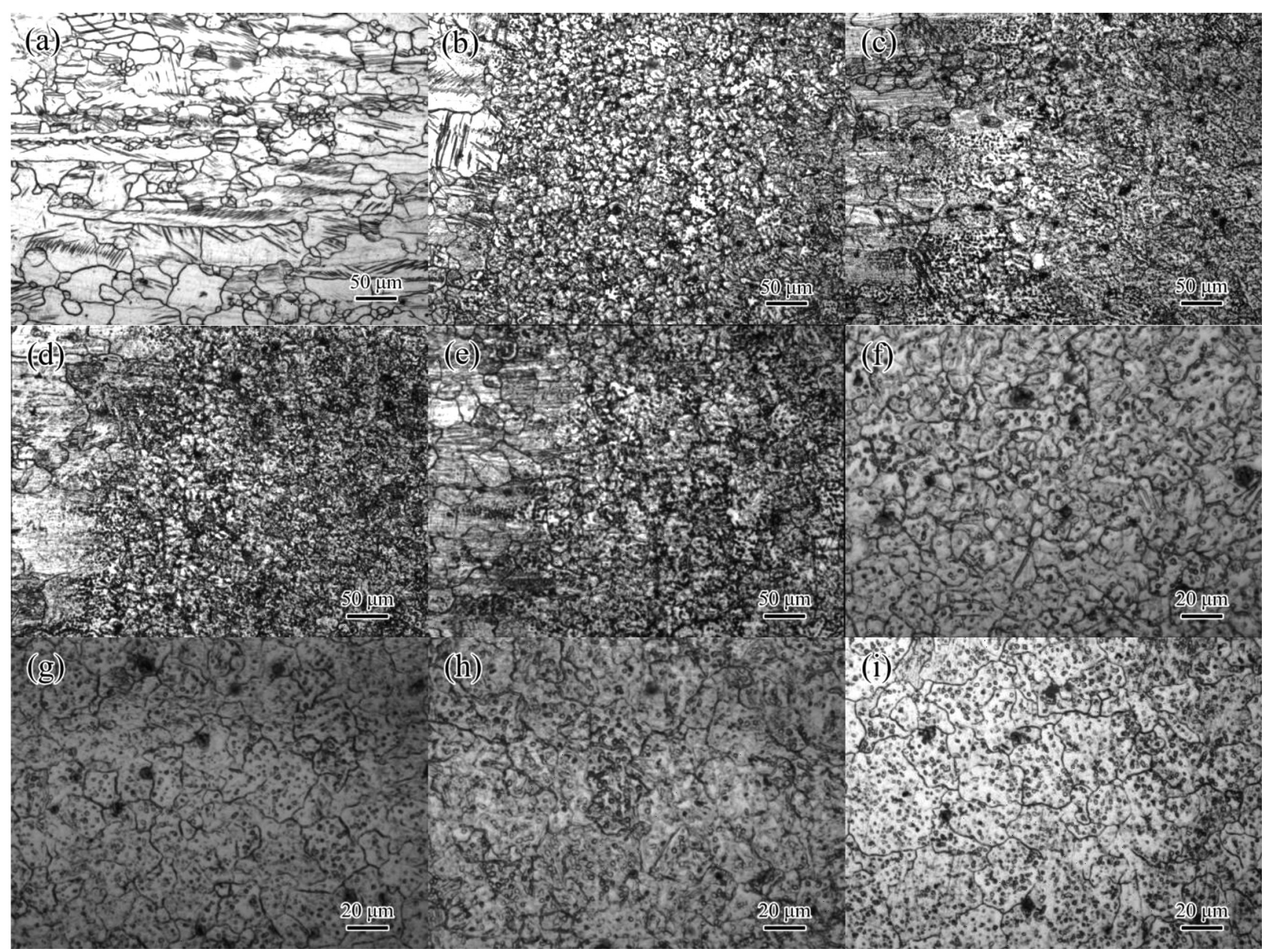

Figure 5: OM photographs of AZ31 joints under different EBW heat inputs: a) BM; microstructure at fusion line with the heat input of: b) $150 \mathrm{~J} \cdot \mathrm{mm}^{-1}$, c) $180 \mathrm{~J} \cdot \mathrm{mm}^{-1}$, d) $216 \mathrm{~J} \cdot \mathrm{mm}^{-1}$, e) $252 \mathrm{~J} \cdot \mathrm{mm}^{-1}$; microstructure of weld centre with the heat input of: f) $150 \mathrm{~J} \cdot \mathrm{mm}^{-1}$, g) $180 \mathrm{~J} \cdot \mathrm{mm}^{-1}$, h) $216 \mathrm{~J} \cdot \mathrm{mm}^{-1}$, i) $252 \mathrm{~J} \cdot \mathrm{mm}^{-1}$ 
cantly broadened. The appearances of the weld changed from nail-shape to straight-shape. It is mainly because more energy will conduct to the bottom from the top with the increasing of heat input. More volume in the bottom of the BM will be melted.

The microstructure of the AZ31 joints under different EBW heat inputs are analyzed using metallographic observations. The microstructure of the as-extruded BM is shown in Figure 5a. The grains are mainly composed of equiaxed grains and directionally elongated columnar grains. The average grain size is about $50 \approx 100 \mu \mathrm{m}$. Some fine recrystallized grains can be observed around the large grains. A few precipitation phases are observed in the BM. Due to the close packed hexagonal lattice and fewer slip systems, twinning is easily activated during plastic deformation at room temperature. ${ }^{18-21}$ Many deformation twins can be seen in the BM. The microstructure near the fusion line of the joints with different heat inputs are shown in Figure $\mathbf{5 b}$ to $\mathbf{5 e}$. The microstructure in the fusion zone adjacent to the BM is similar to that of casting, which has the characteristics of rapid and directional solidification. In Figure 5b, the fine grains with a size of $10-20 \mu \mathrm{m}$ are formed in the fusion zone. With the increasing of heat input, some columnar grains can be observed clearly (Figure 5c). The cause of their formation can be attributed to the larger temperature gradient. In Figure 5d, the grains become significantly larger due to the further increasing of the heat input. In Figure 5e, the grain size is about 1.5 times of that in Figure 5b. The microstructures in weld centre are uniform equiaxed crystal, as shown in Figure $\mathbf{5 f}$ to $\mathbf{5 i}$. The influence of heat inputs on the grain size in the weld centre is quite similar to that near the fusion line. In weld joint with heat input of $150 \mathrm{~J} \cdot \mathrm{mm}^{-1}$, the average size of grains in weld centre is about $15 \mu \mathrm{m}$ (Figure 5f). In Figure 5g, the growth of the grain is obvious. The average grain size is about $20 \mu \mathrm{m}$. In Figure $\mathbf{5 h}$ and $\mathbf{5 i}$, with the increase of heat input, grain sizes further increase. In Figure 5i, the grain size is about $30 \mu \mathrm{m}$, which is two times that in Fig-

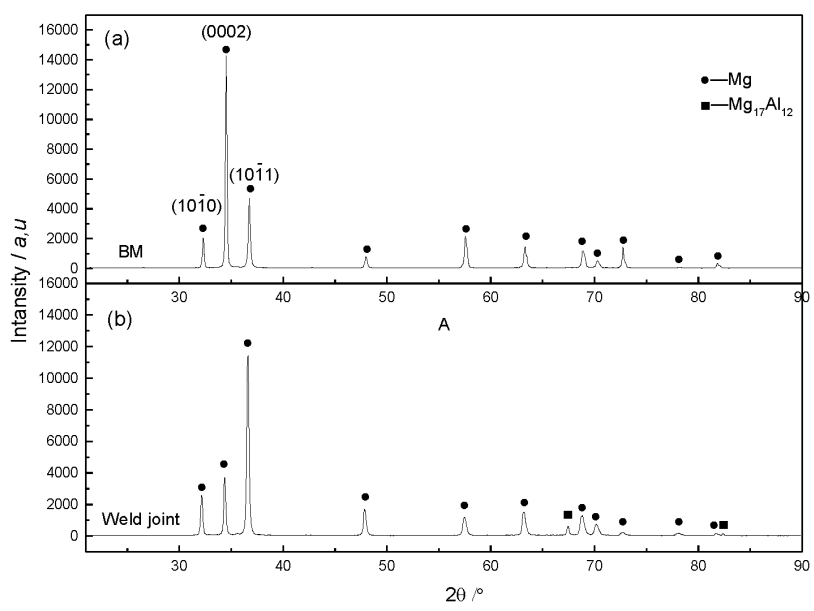

Figure 6: XRD analysis for the AZ31 magnesium alloys: a) BM and b) weld joint with the heat input of $180 \mathrm{~J} \cdot \mathrm{mm}^{-1}$ ure 5f. The increase of heat input provides enough heat driving for the grain growth.

In addition, a large number of dispersed, black, dot-like precipitates can be seen in whole areas of the welds. Many studies have shown that $\mathrm{Mg}_{17} \mathrm{Al}_{12}$ is the most common precipitation in the microstructure of $\mathrm{Mg}-\mathrm{Al}$ alloys welded joint. ${ }^{22-26}$ According to the $\mathrm{Mg}-\mathrm{Al}$ binary phase diagram, aluminum can be dissolved in a magnesium matrix to form $\alpha-\mathrm{Mg}$ during equilibrium solidification. The solid solubility of Al will decrease from 12.6 to $2 w / \%$ during the cooling. The remnant $\mathrm{Al}$ will precipitate the $\mathrm{Mg}_{17} \mathrm{Al}_{12}$ phase. ${ }^{27,28}$ In the AZ31 magnesium alloy, the aluminum content is only about $3 w / \%$. A few $\mathrm{Mg}_{17} \mathrm{Al}_{12}$ phases will be produced during equilibrium solidification. However, $\mathrm{Mg}_{17} \mathrm{Al}_{12}$ phases are easily precipitated in the fusion zone of the EBW joint due to the non-equilibrium solidification. As is shown in Figure $\mathbf{5 b}$ to $\mathbf{5 i}$, the size and quantity of the precipitated phases increase with the increasing of the heat inputs. Because of the increasing heat input, the temperature in the molten pool becomes higher and the cooling rate deceases, which is beneficial for the formation and growth of precipitates.

\subsection{XRD analysis}

In order to determine the preferred orientation and precipitated phases of the BM and joints, XRD analyses were employed, as shown in Figure 6. The results show that $\mathrm{BM}$ is mainly $\alpha-\mathrm{Mg}$ with XRD diffraction peaks at (10-10), (0002) and (10-11), while no diffraction peaks of other precipitated phases can be detected. This is in agreement with the results of the metallographic observation. According to the diffraction peaks of the weld joint, it further verifies that the black dot-like precipitates in Figure $\mathbf{5 b}$ to $\mathbf{5 e}$ are $\mathrm{Mg}_{17} \mathrm{Al}_{12}$ phase. And likewise, the weld structure changes from as-extruded to as-cast after $\mathrm{EBW}$, the preferred orientation is changed from (0002) to $(10-11)$.

\subsection{TEM analysis}

TEM micrographs of AZ31 magnesium alloy EBW samples with a heat input of $180 \mathrm{~J} \cdot \mathrm{mm}^{-1}$ at different deformations are shown in Figure 7. Figures $\mathbf{7 a}$ and $\mathbf{7 b}$ present the precipitates and dislocation of the original joint samples before the tensile deformation. In the centre of the fusion zone, several precipitates gather and stack at $\mathrm{A}$ in Figure 7a. According to the results of the EDS in Table 3, the precipitate mainly contains $\mathrm{Mg}, \mathrm{Al}$ and Mn. These precipitates were not detected by XRD, which may be due to its less total content in the joint. Besides that, several dispersed $\mathrm{Mg}_{17} \mathrm{Al}_{12}$ precipitates with smaller size can also be observed at B. In Figure 7b, a deformation twin with straight grain boundaries is observed in the fusion line region of the weld. The width of the twin is about $0.7 \mu \mathrm{m}$. During the rapid solidification, huge internal stress will occurr in the fusion line region. 


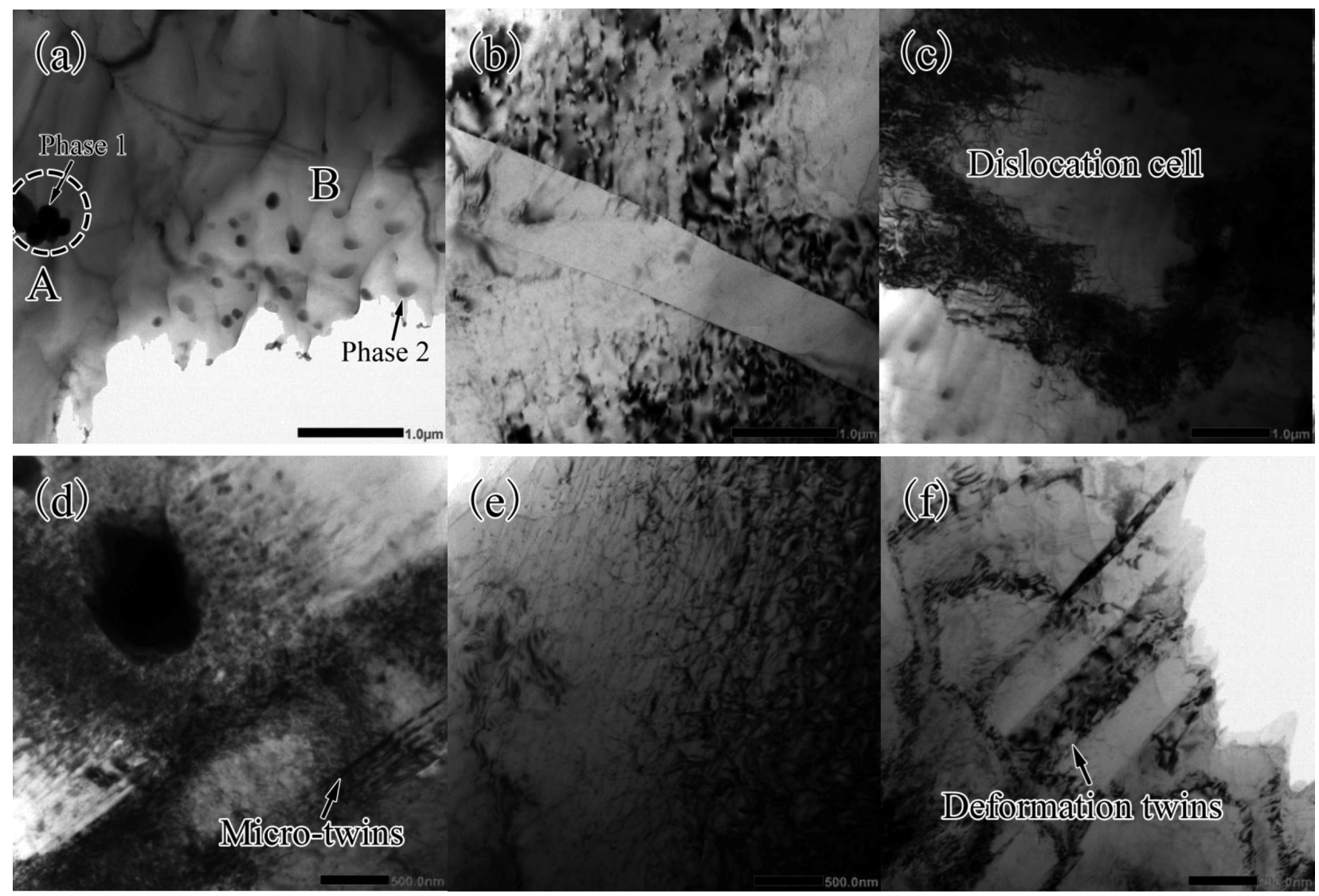

Figure 7: The TEM micrographs of AZ31 magnesium alloy EBW samples with heat input of $180 \mathrm{~J} \cdot \mathrm{mm}^{-1}$ at different deformation: a) and b) samples before tensile deformation, c) and d) samples with $3 \%$ tensile deformation, e) and f) samples with $8 \%$ tensile deformation

Therefore, twins will be more easily formed in this region.

The dislocation morphologies of samples with $3 \%$ tensile deformation are shown in Figures $\mathbf{7 c}$ and $\mathbf{7 d}$. A dislocation cell can be seen in the grain (Figure 7c). The size of the cell was about $2 \mu \mathrm{m}$. In Figure 7d, a large number of dislocations pile up and tangle near the precipitates. Only a few micro-twins with a size of $20 \mathrm{~nm}$ are found. It shows that the deformation mechanism is still dominated by basal slip at this stage.

In the EBW sample with $8 \%$ tensile deformation, some nano precipitates with smaller size are found, as is shown in Figure 7e. Because the sizes of these nano precipitates are too small, the type of precipitates is not clear yet. These nano precipitates inhibit the dislocation movement by the pinning effect. The bowing of dislocations can be observed between the nano precipitates. In Figure 7f, the deformation twins become larger in size compared with the twins in Figure 7d.

Table 3: Compositional analysis to the precipitated phases

\begin{tabular}{|c|c|c|c|}
\hline & $\mathrm{Mg}(w / \%)$ & $\mathrm{Al}(w / \%)$ & $\mathrm{Mn}(w / \%)$ \\
\hline Phase 1 & 18.62 & 43.71 & 37.67 \\
\hline Phase 2 & 55.77 & 44.23 & - \\
\hline
\end{tabular}

\subsection{Fractography}

All the tensile specimens are fractured in the welds, and the fracture modes are the same. Figure 8 shows one of fractured specimens of AZ31 magnesium alloy EBW joint with heat input of $180 \mathrm{~J} \cdot \mathrm{mm}^{-1}$. The crack initiates at the fusion line, then runs across the middle of the weld, as is shown in Figure 8b.
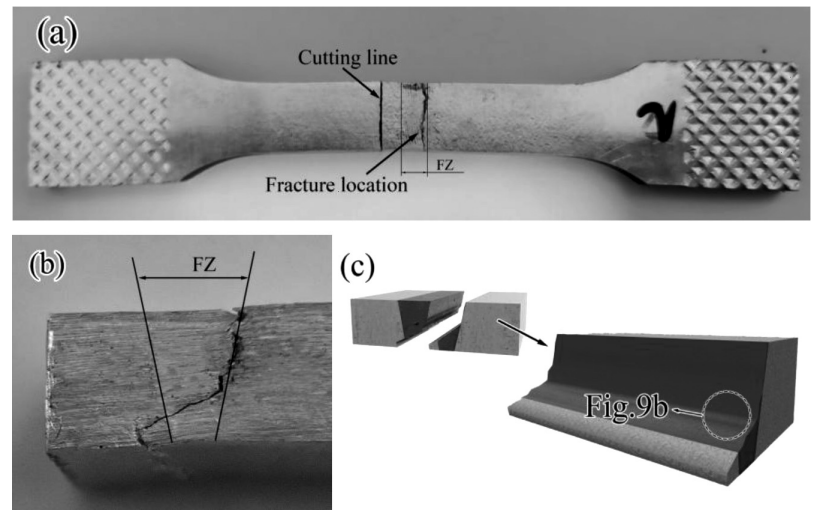

(c)

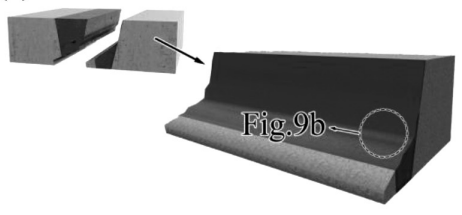

Figure 8: Fractured specimens of AZ31 magnesium alloy EBW joint with heat input of $180 \mathrm{~J} \cdot \mathrm{mm}^{-1}$ a) top view of the fracture specimen, b) front view of the fracture specimen, c) 3D schematic of the fracture specimen 

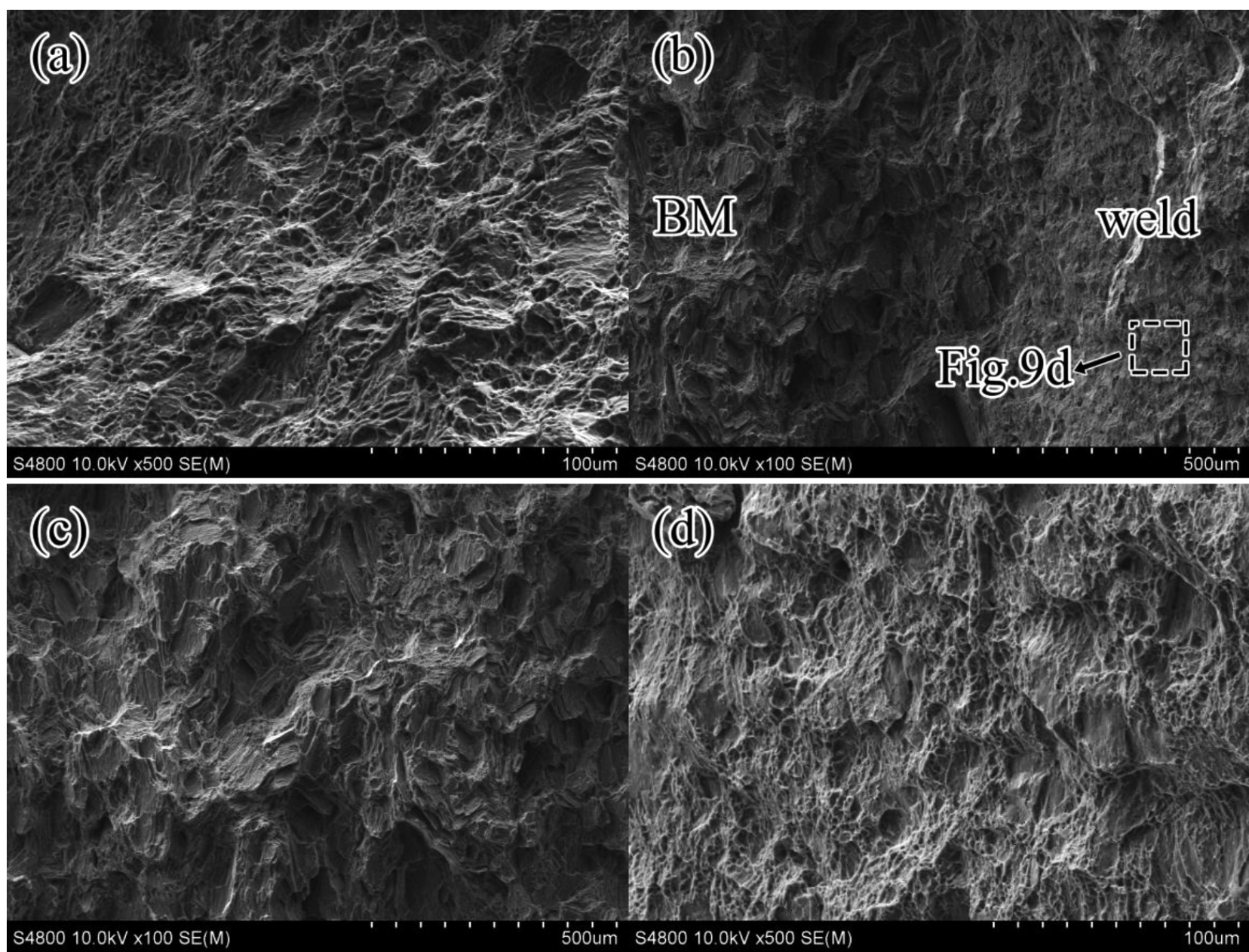

Figure 9: SEM fractography of tensile test specimens: a) fractography of BM, b) fractography of the weld joint with the heat input of $\left.180 \mathrm{~J} \cdot \mathrm{mm}^{-1}, \mathrm{c}\right)$ partial enlarged image of the BM side in Figure $\mathbf{9 b}, \mathrm{d}$ ) partial, enlarged image of the weld side in Figure $\mathbf{9 b}$

Figure 9a is the SEM fractography of BM specimen. It shows mixed fracture morphology features of quasicleavage and dimple morphology. The fractography of the AZ31 EBW joint with heat input of $180 \mathrm{~J} \cdot \mathrm{mm}^{-1}$ are shown in Figures $\mathbf{9 b}$ to $\mathbf{9 d}$. Figure $\mathbf{9 b}$ shows the fracture morphology near the weld fusion line. A significant morphological difference was observed. The fracture morphology in the BM side is polyhedral, which is generally intergranular fracture (Figure 9c). However, the polyhedral fracture is not obvious in the fusion region of the weld. Instead, a large number of fine dimples were observed by high magnification (Figure 9d).

\section{DISCUSSION}

As mentioned in Section 3.1, the strength and ductility increase first and then decrease with increasing of heat inputs. It is closely related to the microstructure of the samples.

Because of the rapid cooling of EBW, the diffusion time of solute in the molten pool is very short. The nucleation of each phase is rapidly, and most of $\mathrm{Al}$ atoms cannot return to the grain boundary in time. ${ }^{29}$ The precip- itates $\mathrm{Mg}_{17} \mathrm{Al}_{12}$ will nucleate intra-granularly and grow directly at their present positions. The dislocations are pinned by the precipitated-phase particles during basal slip. With the increase of welding heat input, the molten pool will stay at high temperature for a longer period of time. More $\mathrm{Al}$ atoms in weld metal will be fully precipitated. In addition, the evaporation of magnesium increases with the increase of heat input, which results in the increase of the relative aluminum content. ${ }^{30}$ It also facilitates the formation of the precipitated phase. As shown in Figure 5, with the increasing of the heat input, the amount of precipitated phase increases in grains. $\mathrm{Nu}$ merous studies showed that the strength of welded joints would be affected by the number and size of precipitates. ${ }^{30-32}$ When the heat input is $180 \mathrm{~J} \cdot \mathrm{mm}^{-1}$, the tensile strength is the highest. During plastic deformation, the increase of precipitate phases provides more obstacles for dislocation movement in the matrix. As a hard phase, $\mathrm{Mg}_{17} \mathrm{Al}_{12}$ is not coherent with matrix. Its elastic modulus is much higher than that of the matrix. These characteristics determine that free dislocations will bow out when pinned by precipitates (Figures 7d and 7e). Subsequently, more dislocations interact, pile up and tangle. 
The bowing and tangling of high-density dislocations will increase the lattice distortion energy of the dislocation area, which will further increase the resistance of the dislocation movement. From the macroscopic view, the strength of materials will be greatly improved. In Figures $5 \mathbf{c}$ and $\mathbf{5 g}$, the precipitation phases with fine size and dispersion distribution can be observed. Generally, the fine and dispersed precipitates are also conducive to improving the strength of the material. In contrast, a continuous distribution of precipitates is more likely to induce local cracks. It leads to the early fracture of specimens during tensile deformation. When the heat input is greater than $216 \mathrm{~J} \cdot \mathrm{mm}^{-1}$, the amount of the precipitation tends to be saturated, which is no longer the primary factor affecting the strength of the material. According to the Hall-Petch formula, ${ }^{33,34}$ the smaller the grain size, the higher the material strength. With large heat input, coarse grains in weld will result in the decease of strength.

For the ductility, with the increase of heat input, the increase of grain size and precipitation phase are not conducive to improving the ductility of the specimens. However, combined with the macro and micro morphology of the welds, it can be seen that the increasing of heat input results in an increase of the weld width. The macro morphologies of the welds changed from nail-shape to straight-shape. Compared with the nail-shape, the straight weld shape is more conducive to reducing the stress concentration during tensile deformation. This explains that why the ductility of the material increases first and then decreases, and reaches the maximum value of ductility when the heat input is $216 \mathrm{~J} \cdot \mathrm{mm}^{-1}$.

In many earlier studies on the deformation mechanism of magnesium alloy, it revealed that basal slip and $\{10-12\}$ tensile twinning are the most common deformation mechanisms of magnesium alloys at room temperature due to their small critical resolved shear stresses. ${ }^{35-37}$ In Figure 7, many dislocations and twins are observed. There are only two independent slip systems for the basal slip, which can only satisfy the deformation perpendicular to the c-axis. While the $\{10-12\}$ tensile twinning provides for deformation along the c-axis. ${ }^{36}$ The basal slip and tensile twinning coordinate and compete with each other during the tensile deformation at room temperature. For welded joints, the deformation is dominated by slip mechanism at small tensile deformation. Lynch et al. ${ }^{38}$ found that the basal slip is activated prior to twinning in the study of plastic deformation of a magnesium alloy. Wang et al. ${ }^{39}$ found that when the tensile strain is less than 0.02 , the deformation is dominated by basal slip. The twin mechanism is activated at larger deformation. The deformation twins will nucleate and grow as shown in Figure 7d and 7f. In the study of Cepeda et $\mathrm{al},{ }^{40}$ the effect of grain size on the dominant deformation mechanism of pure magnesium during deformation was investigated. It was found that the domi- nant deformation mechanism changes from twinning to slip when the grain size decreases from $19 \mu \mathrm{m}$ to $5 \mu \mathrm{m}$. During tensile deformation, the deformation mechanism in the fusion zone is mainly dominated by basal slip due to the small size of the grains. Therefore, the centre of weld has better plasticity. In contrast, the grain sizes are much bigger in the BM. The deformation mechanism is mainly twinning. In addition, because of the rapid heating and cooling in the fusion line region where adjacent to the BM. Huge internal stresses will be generated in this area, and many twins will form. Although the appearance of deformation twins played an important role in deformation coordination. During large plastic deformation, these twins which formed during welding have poor deformation ability. And the twin boundary will further hinder the slip of the movable dislocation. Large local internal stress exists at the deformation twin boundaries. With the increasing of the local internal stress, the crack finally appears. Therefore, cracks are more likely to occur in the fusion zone adjacent to the BM. This explains why the fracture mechanism in the center of weld is a ductile fracture, while the fracture near the BM is a brittle cleavage fracture.

\section{CONCLUSIONS}

(1) The strengths of weld joints are higher than those of the BM. However, the ductility becomes much worse after EBW. The heat input plays a key role in EBW for AZ31 magnesium alloy extrusion plates. Both the strength and ductility exhibited a trend of increasing first and then decreasing with increasing heat inputs. The specimen with heat input of $180 \mathrm{~J} \cdot \mathrm{mm}^{-1}$ has the best strength. The YS and UTS are 216.6 MPa and 290.4 $\mathrm{MPa}$, which increase by $121.5 \mathrm{MPa}$ and $57.2 \mathrm{MPa}$ compare with BM. With the heat input of $216 \mathrm{~J} \cdot \mathrm{mm}^{-1}$, the value of the elongation and the reduction of the cross-sectional area are relatively high, and are only 2.9 $\%$ and $2.5 \%$ smaller than the BM.

(2) With the increase of heat input, the top side of the weld is slightly broadened, and the bottom of the weld is significantly broadened. The appearances of the weld changed from nail-shape to straight-shape which is more conducive to reduce the stress concentration during tensile deformation. It is mainly because more energy will conduct to the bottom from the top with the increasing of the heat input. More volume in the bottom of the BM will be melted.

(3) With the increase of the heat input, the grains in the fusion zone become coarser. Many $\mathrm{Mg}_{17} \mathrm{Al}_{12}$ precipitates are observed in the grains of the weld. A large heat input leads to an increase of the quantity and size of precipitates in weld. These precipitates effectively restrict the dislocation movement and improve the strength.

(4) Significant fracture morphological differences between the fusion zone and BM can be found. The fracture morphology in the BM side is polyhedral, which is 
generally intergranular fracture. However, the brittle fracture is not obvious in the fusion zone of the weld. Instead, a large number of fine dimples are observed by high magnification.

\section{Acknowledgment}

The work was supported by National Natural Science Foundation of China (No.51875384), "1331 project" of Shanxi Province, China (welding engineering center, welding technology and engineering provincial advantage specialty), Hundred-Talent Program of Shanxi Province, China and Internet $+3 \mathrm{D}$ printing Collaborative Innovation Center of Shanxi Province, China. The authors also expressed gratitude to the colleagues of the Shanxi Fenxi Heavy Industry Co., Ltd.

\section{REFERENCES}

${ }^{1}$ S. Mironov, T. Onuma, Y. S. Sato, S. Yoneyama, H. Kokawa, Microstructural changes during tension of friction-stir welded AZ31 magnesium alloy, Mater. Charact., 130 (2017), 1-8, doi:10.1016/ j.matchar. 2017.05.016

${ }^{2}$ M. Gao, H. Wang, K. Hao, H. Mu, X. Zhang, Evolutions in microstructure and mechanical properties of laser lap welded AZ31 magnesium alloy via beam oscillation, J. Manuf. Process., 45 (2019), 92-99, doi:10.1016/j.jmapro.2019.07.001

${ }^{3}$ G, Padmanaban, V. Balasubramanian, Effects of laser beam welding parameters on mechanical properties and microstructure of AZ31B magnesium alloy, T Nonferr Metal Soc., 21 (2011) 9, 1917-1924, doi:10.1016/s1003-6326(11)60950-3

${ }^{4}$ T. Mukai, M. Yamanoi, H. Watanabe, K. Higashi, Ductility enhancement in AZ31 magnesium alloy by controlling its grain structure, Scripta Mater., 45 (2001) 1, 89-94, doi:10.1016/s1359-6462(01) 00996-4

${ }^{5}$ A. Styczynski, C. Hartig, J. Bohlen, D. Letzig, Cold rolling textures in AZ31 wrought magnesium alloy, Scripta Mater., 50 (2004) 7, 943-947, doi:10.1016/j.scriptamat.2004.01.010

${ }^{6}$ Z. Sun, D. Pan, J. Wei, Comparative evaluation of tungsten inert gas and laser welding of AZ31 magnesium alloy, Sci. Technol. Weld. Joi., 7 (2002) 6, 343-351, doi:10.1179/136217102225006831

${ }^{7}$ C. T .Chi, C. G. Chao, T. F. Liu, C. H. Lee, Aluminum element effect for electron beam welding of similar and dissimilar magnesium-aluminum-zinc alloys, Scripta Mater., 56 (2007) 9, 733-736, doi:10.1016/j.scriptamat.2007.01.028

${ }^{8}$ C. T .Chi, C. G. Chao, Characterization on electron beam welds and parameters for AZ31B-F extrusive plates, J Mater. Process. Technol., 182 (2007) 1-3, 369-373, doi:10.1016/j.jmatprotec.2006.08.024

${ }^{9}$ Z. Sun, R. Karppi, The application of electron beam welding for the joining of dissimilar metals: an overview, J Mater. Process. Technol., 59 (1996) 3, 257-267, doi:10.1016/0924-0136(95)02150-7

${ }^{10}$ P. Petrov, C. Georgiev, G. Petrov, Experimental investigation of weld pool formation in electron beam welding, Vacuum, 51 (1998) 3 , 339-343, doi:10.1016/S0042-207X(98)00110-9

${ }^{11}$ M. Ahmad, J. I. Akhter, M. Akhtar, M. Iqbal, E.Ahmed, M. A. Choudhry, Microstructure and hardness studies of the electron beam welded zone of Hastelloy C-276, J. Alloy. Compd., 390 (2005) 1-2, 88-93, doi:10.1016/j.jallcom.2004.08.031

${ }^{12}$ Z. Zhang, H. Jing, L. Xu, Y. Han, L. Zhao, Influence of heat input in electron beam process on microstructure and properties of duplex stainless steel welded interface, Appl. Surf. Sci., 435 (2018), 352-366, doi:10.1016/j.apsusc.2017.11.125

${ }^{13}$ F. Gao, Q. Gao, P. Jiang, Z. Liu, Z. Liao, Microstructure and properties of titanium alloy electron beam weldments based on the different heat input conditions of the same line energy, Vacuum, 146 (2017), 136-141, doi:10.1016/j.vacuum.2017.09.038

${ }^{14}$ G. M. Reddy, T. Mohandas, A. S. Rao, V. V. Satyanarayana, Influence of Welding Processes on Microstructure and Mechanical Properties of Dissimilar Austenitic-Ferritic Stainless Steel Welds, Mater and Manuf. Process., 20 (2005) 2, 147-173, doi:10.1081/AMP200041844

${ }^{15}$ J. Feng, H. Wu, J. He, B. Zhang, Microstructure evolution of electron beam welded Ti3Al-Nb joint, Mater. Charact., 54 (2005) 2, 99-105, doi:10.1016/j.matchar.2004.11.006

${ }^{16}$ C. T. Chi, C. G. Chao, T. F. Liu, C. C. Wang, Relational analysis between parameters and defects for electron beam welding of AZ-series magnesium alloys, Vacuum, 82 (2008) 11, 1177-1182, doi:10.1016/j.vacuum.2007.12.019

${ }^{17}$ S. F. Su, J. C. Huang, H. K. Lin, N. J. Ho, Electron-beam welding behavior in Mg-Al-based alloys, Metall. Mater. Trans. A, 33 (2002) 5, 1461-1473, doi:10.1007/s11661-002-0069-6

${ }^{18}$ C. Lou, X. Zhang, G. Duan, J. Tu, Q. Liu, Characteristics of Twin Lamellar Structure in Magnesium Alloy during Room Temperature Dynamic Plastic Deformation, J. Mater. Sci. Technol., 30 (2014) 1, 41-46, doi:10.1016/j.jmst.2013.08.003

${ }^{19}$ P. Molnár, A. Ostapovets, A. Jäger, Reversible motion of twin boundaries in AZ31 alloy and new design of magnesium alloys as smart materials, Mater. Des., 56 (2014), 509-516, doi:10.1016/j.matdes. 2013.11.055

${ }^{20}$ C. Lou, X. Y. Zhang, R. H. Wang, Q. Liu, Mechanical behavior and microstructural characteristics of magnesium alloy containing \{10-12\} twin lamellar structure, J. Mater. Res., 28 (2013) 5, 733-739. doi:10.1557/jmr.2012.394

${ }^{21}$ F. Mokdad, D. L. Chen, D. Y. Li, Single and double twin nucleation, growth, and interaction in an extruded magnesium alloy, Mater. Des., 119 (2017), 376-396, doi:10.1016/j.matdes.2017.01.072

${ }^{22}$ M. X. Zhang, P. M. Kelly, Crystallography of Mg17A112 precipitates in AZ91D alloy, Scripta Mater., 48 (2003) 5, 647-652, doi:10.1016/s1359-6462(02)00555-9

${ }^{23}$ Y. R. Wang, J. C. Feng, Z. D. Zhang, Microstructure characteristics of resistance spot welds of AZ31 Mg alloy, Sci. Technol. Weld. Joi., 11 (2006) 5, 555-560, doi:doi:10.1179/174329306x128446

${ }^{24}$ S. Chai, D. Zhang, F. Pan, J. Dong, F. Guo, Y. Dong, Influence of post-weld hot rolling on the microstructure and mechanical properties of AZ31 magnesium alloy sheet, Mater. Sci. Eng. A, 588 (2013), 208-213, doi:10.1016/j.msea.2013.09.020

${ }^{25}$ S. Liu, D. Q. Sun, X. Y. Gu, H. Li, Microstructures and mechanical properties of metal inert-gas arc welded joints of $\mathrm{Mg}$ alloy and ultra-high strength steel, J. Mater. Res., 32 (2017) 4, 843-851, doi:10.1557/jmr.2016.515

${ }^{26}$ U. Suhuddin, V. Fischer, F. Kroeff, J. F. dos Santos, Microstructure and mechanical properties of friction spot welds of dissimilar AA5754 Al and AZ31 Mg alloys, Mater. Sci. Eng. A, 590 (2014), 384-389, doi:10.1016/j.msea.2013.10.057

${ }^{27}$ Y. Turen, Effect of Sn addition on microstructure, mechanical and casting properties of AZ91 alloy, Mater. Des., 49 (2013), 1009-1015, doi:10.1016/j.matdes.2013.02.037

${ }^{28}$ S. Kleiner, E. Ogris, O. Beffort, P. J. Uggowitzer, Semi-Solid Metal Processing of Aluminum Alloy A356 and Magnesium Alloy AZ91: Comparison Based on Metallurgical Consideration, Adv. Eng. Mater., 5 (2003) 9, 653-658, doi:10.1002/adem.200300358

${ }^{29}$ Y. J. Quan, Z. H. Chen, X. S. Gong, Z. H. Yu, Effects of heat input on microstructure and tensile properties of laser welded magnesium alloy AZ31, Mater. Charact., 59 (2008) 10, 1491-1497, doi:10.1016/j.matchar.2008.01.010.

${ }^{30}$ Y. Luo, J. Liu, Microstructural evolution in AZ91D magnesium alloy during electron beam welding, Vacuum, 85 (2011) 11, 1004-1010, doi:10.1016/j.vacuum.2011.02.009

${ }^{31}$ J. F. Nie, Effects of precipitate shape and orientation on dispersion strengthening in magnesium alloys, Scripta Mater., 48 (2003) 8 , 1009-1015, doi:10.1016/s1359-6462(02)00497-9 


\section{JINQIU et al.: EFFECT OF HEAT INPUT ON THE MICROSTRUCTURE AND MECHANICAL PROPERTIES ...}

${ }^{32}$ J. D. Robson, N. Stanford, M. R. Barnett, Effect of precipitate shape on slip and twinning in magnesium alloys, Acta Mater., 59 (2011) 5 , 1945-1956, doi:10.1016/j.actamat.2010.11.060

${ }^{33}$ E. O. Hall, The Deformation and Ageing of Mild Steel: II Characteristics of the Luders Deformation, Proc.Phys.Soc.b, 64 (1951) 9, 742, doi:10.1088/0370-1301/64/9/302

${ }^{34}$ S. Y. Sato, M. Urata, U. H. Kokawa, K. Ikeda, Hall-Petch relationship in friction stir welds of equal channel angular-pressed aluminium alloys, Mater. Sci. Eng. A, 354 (2003) 1-2, 298-305, doi:10.1016/s0921-5093(03)00008-x

${ }^{35}$ M. R. Barnett, M. D. Nave, C. J. Bettles, Deformation microstructures and textures of some cold rolled $\mathrm{Mg}$ alloys, Mater. Sci. Eng. A, 386 (2004) 1-2, 205-211, doi:10.1016/j.msea.2004.07.030

${ }^{36}$ R. Xin, C. Guo, Z. Xu, G. Liu, X. Huang, Q. Liu, Characteristics of long $\{10-12\}$ twin bands in sheet rolling of a magnesium alloy, Scripta Mater., 74 (2014), 96-99, doi:10.1016/j.scriptamat.2013. 11.008
${ }^{37}$ S. H. Park, S. G. Hong, C. S. Lee, Activation mode dependent $\{10-12\}$ twinning characteristics in a polycrystalline magnesium alloy, Scripta mater, 62 (2010) 4, 202-205, doi:10.1016/j.scriptamat. 2009.10.027

${ }^{38}$ P. A. Lynch, M. Kunz, N. Tamura, M. R. Barnett, Time and spatial resolution of slip and twinning in a grain embedded within a magnesium polycrystal, Acta Mater., 78 (2014), 203-212, doi:10.1016/ j.actamat.2014.06.030

${ }^{39}$ J. Wang, D. Ju, F. Yin, H. Zhao, Microstructure evaluation and crack initiation crack for AZ31 sheet under biaxial stress, Procedia Eng., 10 (2011), 2429-2434, doi:doi:10.1016/j.proeng.2011.04.400

${ }^{40}$ C. M. Cepeda-Jiménez, J. M. Molina-Aldareguia, M. T. Pérez-Prado, Origin of the twinning to slip transition with grain size refinement, with decreasing strain rate and with increasing temperature in magnesium, Acta Mater., 88 (2015), 232-244, doi:10.1016/j.actamat. 2015.01.032 